DOI https://doi.org/10.30525/978-9934-26-039-1-34

\title{
PECULIARITIES OF FOLK BALLADS
}

\author{
Cholakova A. D. \\ Ph. D. in Philology, \\ Professor at the Department of Foreign Languages \\ Kharkiv National I. P. Kotlyarevsky University of Arts \\ Babaievska L. V. \\ Senior Lecturer at the Department of Foreign Languages \\ Kharkiv National I. P. Kotlyarevsky University of Arts \\ Kharkiv, Ukraine
}

The oral ballad belongs to the early medieval epico-lyric genres. The creators of written ballads were the troubadour knights who, in the 11th century in the South of France, in the province of Provence, managed to sprout elements of dance and song from the folk form. The term «ballad» comes from the Provencal 'ballard' - to dance, a dance song.

The verbal ballad became widespread in the Western European folk poetry, where Scottish, Irish and Celtic works undoubtedly occupy the leading position. In Slavic folklore culture, this form emerged much later than the Russian epos, presumably in the XVII - XVIII centuries, although scientists can shift the time, adding several more centuries for solidity. Such arbitrariness is scientifically groundless and tendentiously discussed in literature.

Genre peculiarities of the ballad. A folk ballad, just like a literary one, is characterized by invariable dominant features. These include: a) a dynamic, action-packed plot; unexpected outcome; dialogicity and numerical symbolism; b) the presence of a fantastic layer; c) event-related ballad secret; d) the cruelty of the ballad evil; the presence of this element permits to call the ballad a «cruel genre», where the meek and innocent usually die, and the carriers of evil go unpunished.

The object of the folk ballad depiction. The works of the genre under consideration depict the destinies of people, not the interests of the society, city state or governor. The main character of the ballad, as a victim, is not one of the bogatyrs (legendary East Slavic heroes), their story is confined to the boundaries of family (private) life. This material makes it possible to outline the tragic event which the character goes through. The system of murder, torture, revenge (vengeance), and deceit reveals the state of mind, confirming 
that this genre has entered the period of artistic research of both behavioral and psychological mysteries of character studies.

In anthologies and separate textbooks, the authors can refer the same ballad text to a ballad or a historical song. These texts, in their structure and methodology of presenting events, are really close to each other, but they belong to different types of verbal folklore.

Poetics of the ballad 'A knyaz Roman zhenu teryal' (Prince Roman lost his wife). The plot of the work is developed according to the rules of a cruel event: the husband has killed his young wife, and the body is dismembered and thrown into the river. The mystery is established through dialogue. The daughter, Anna Romanovna, asks her father a question twice and both times the Prince evasively avoids answering.

The daughter's first appeal to her father: 'Gde ty deval moyu matushku?' (What did you do with my mother?) The answer is framed in an allegorical form and sounds almost believable: 'Ushla tvoya matushka mytsya, ...v tsvetnoe platye naryazhatisya' (Your mother has gone to take a bath, ...to dress up in a colored dress). The daughter and the maids go to watch the mother bathing in the palace, but she is not found there.

The daughter's second appeal to her father: 'What did you do with my mother?' - compels us to give a more specific answer: 'Ushla tvoya matushka vo zelenyy sad' (Your mother has gone to the green garden). This information brings the search closer to the secret. Soon the seekers see a fantastic picture: a blue-grey eagle carries a 'white hand' with a gold ring in its talons and drops it to the ground. The process of recognizing the hand takes place.

The final of the ballad plot. In the river the maids find the head and bones of the murdered mother. The tragic event ends with the burial of the collected body parts.

There is another mystery in this ballad. The collective author obscured the history of the family conflict, so the reason for the death of the main female character remains unknown. The carrier of evil, in relation to the genre requirements, remains unpunished, but emotionally and didactically his deed is condemned by the listeners.

Techniques of ballad portraying. In the ballad song 'Prince Roman lost his wife', the victim is characterized by portrait features. The portrait of the mother is simply dismembered. It uses the artistic technique of sculptural portraiture, which is well-known in verbal folklore.

Among folklore ballads, a group of epico-lyric works with a clearly defined family conflict stands out. So, in the ballad 'Vspoil, vskormil otets syna' (The father raised and brought up his son), the head of the family disliked his son for some unknown reason (the Oedipus complex?) and drove 
him out of the house. Here is a hint at the reason for the cruel act: the father is sure that such exile will make the son appreciate the parental hearth.

Three sisters ask the brother when he will return home. The answer corresponds to the folklore metaphorical formula. The brother says that he will return when the sand comes up and sprouts in the garden, i.e. never.

The development of the plot is fixed by years: nine years have passed since the exile, in the tenth year the sisters decide to look for their brother. This decision switches the real plot into something incredible, magic: the elder sister looks for her brother ' $v$ more shchukoyu' (in the sea as a pike), the middle one - ' $v$ pole sokolom' (in the field as a falcon), the youngest - ' $v$ nebe zvezdoyu' (in the "sky as a star). And they find him killed in the Saratov steppe. The final is resolved by burial, mourning and home-coming.

Folk love ballads. Folk ballads can have purely amorous themes. As a rule, in this class of songs, moralizing is moved to the final part of the plot. An example is the ballad 'Kak u nas-to bylo, bylo vo zelenom sadu' (Once, it happened in a green garden). The meaning of the work is as follows: the sweetheart tests his girlfriend; she must poison her brother, who does not approve of her sister's choice. And when the tragedy has occurred, the sweetheart rejects the main character:

Kol umela ty brattsa izvest,

Izvedesh i menya, molodtsa,

Ostavaysya zh ty teper odna!

As you were able to kill your brother

You'll easily get rid of me the young,

So stay alone for all you've done!

The cruelty of her act leads the main character to the tragic understanding of what she has done: 'Izvela ya brata rodimogo, I lishilas druga lyubimogo' (I have killed my dear brother, and I've lost my favoured friend).

The ballad 'Once, it happened in a green garden' depicts 'horror' at the effects of the deadly potion: the girl 'kapnula konyu na grivu - u konya griva zagoralasya, a... usta u brata krovyu zapeklisya' (dropped some poison on the horse's mane - the horse's mane began to burn, and ... brother's mouth was full of clotted blood). The frequency of the use of set epithets in the folk ballad is extremely high ('zelenyy sad' - green garden, 'grusha zelena' - green pear, 'zeleno vino' - acid wine).

Poetics of the finals of folklore ballads. Ballad events have a tragic ending. This is connected not with the psychology of the people's creativity, but with the requirements of the genre, which dictates the conditions according 
to the rules of «memory of the genre». Thus, the ballad 'Ne bela li lebedka $v$ perelet letit' (It is not a white swan flying to the far land) ends with a suicide: 'Kidalas krasna devitsa v Daryu-reku, Tonula krasna devitsa, slovno klyuch ko $d n u$ ' (The pretty girl threw herself into the Daria River, the pretty girl went to the bottom like a key; in the ballad 'Gulyal molodets po Ukraine' (A young lad was walking around Ukraine) the ending is cruel and bloody: 'Rubili by golovy donoschikam, Kto donosil na korolevnu' (They would chop off the heads of the informers, Who peached on the princess); in the ballad 'Vo Moskve bylo u knyazya Volkhonskogo' (Prince Volkhonsky had it in Moscow) - 'Ivanushka po petelke kachaetsya, A knyaginya-to $v$ tereme konchaetsya' (Ivanushka is swaying on a loop, And the princess is dying in the palace).

There are a few ballads, the plot of which begins with the death of protagonists.

In the evolution of the folklore ballad, new elements appear in the plot changing its structure, which confirms the fact of the influence of other literary genres, for example, songs and romances. Folk ballads admit synthesis with such folklore genres as paroemias, episodes of the ritual poetry. Thus, the ballad 'Once, it happened in a green garden' depicts a picture of witchcraft:

Koster klavshi, ona zmeyu pekla,

Zmeyu pekla, pepel veyala,

Pepel veyala, zele delala,

Sostav sostavlyala $v$ zelenom vine...

Having set the fire, she baked a snake,

She baked a snake and blew the ashes,

She blew the ashes, she made a potion,

She brewed the potion in acid wine...

The poetics of the ballad differs from other folklore genres by the distance between the art of the folk poet and the eventual picture and system of images he recreated. This increases the importance of talent and acquired skill, since the ballad is less subject to arrangement.

\section{References:}

1. Народные баллады. М.-Л., 1963. 449 с.

2. Путилов Б.Н. Славянская историческая баллада. М.-Л.: Наука, 1965. $174 \mathrm{c}$. 